theme 1

theory

author(s) strand 1

histories of design criticism

Robin Fuller rofuller@tcd.ie

Trinity College, Dublin
Blucher Design Proceedings

Dezembro de 2014, Número 5, Volume 1

\title{
Jean Baudrillard, design theorist
}

This paper argues that the writings of cultural-theorist Jean Baudrillard from the late 1960 s and early 1970 s provided an important contribution to twentieth-century Design Theory. Baudrillard's theory of consumer society was informed by a critical engagement with themes that preoccupied twentieth-century design practice and theory. Rejecting the designer's testimony as evidence, Baudrillard insisted that design be understood within the broader sociological context of consumer society. Towards the close of the 1960s, as the universalist project of Functionalism was attacked by various factions, Baudrillard uniquely argued that Functionalism had not simply failed to establish a singular mode of design in opposition to the multiplicity of fashion; rather Functionalism was fashion's progenitor and perfect exemplar.

keywords functionalism, Jean Baudrillard, design theory, twentieth century

\section{Introduction}

Design Theory may ask 'what is the role of design within society?', or 'how should we design?' The pursuit of each of these questions may not produce complementary results. An emphasis on the methods and intentions of the designer potentially produces a distorted view of the sociological function of design. In his earliest major works, published between 1968 and 1972 - Le Système des objets, La Société de consommation, and Pour une critique de l'économie politique du signe - Baudrillard situated an account of design within a theory of consumer society, rejecting the prioritised perspective of the designer. The search for a universal mode of design which had dominated early twentieth-century Design Theory, increasingly came under attack in the late 1960s and early 1970s. Against the vision of a singular course for design history, Robert Venturi (1966) celebrated 'complexity and contradiction', Charles Jencks (1973) described a 'plurality of approaches', and Archizoom Associati attacked 'the optimistic view of bourgeois progress' (Branzi 1984: 55).

Concurrently Baudillard developed his critique of Functionalism, often in Utopie, a journal featuring contributions from architects including Jean Aubert and Jean-Paul Jungmann (Buckley and Violeau, 2011). However, Baurdillard did not champion 'pluralistic' design against modernist universalism. Rather, he claimed an all-consuming universal system fashion — had already been irrevocably imposed. 


\section{Signs, symbols and objects}

The defining design theory of the first half of the twentieth century was Functionalism. Although the term was often rejected - Walter Gropius, for example, claimed Functionalism was a 'false slogan inspired by plagarism' (Gropius 1935: 19) - nevertheless, from Hermann Muthesius to Herbert Read (and as late as Victor Papanek) we find some variation of the following view: authentic modern design will reject the coexistence of multiple styles and design according to the demands of instrumental purpose. That is to say, Functionalism was not simply the slogan 'form follows function', but a belief in the necessity of a coherent design culture for the twentieth century, and the belief that the path towards this would require rejection of ornament and fashion, and attention to use and need. This view presupposes that the primary use of an object can be easily determined, and that stylistic aspects of design are secondary. Baudrillard's radical critique of this view challenges the very notions of use and need.

In the twentieth century, Baudrillard writes, human ecology underwent a profound change, as our interactions became chiefly with 'objects' rather than 'fellow human beings, as they were in all previous ages' (Baudrillard 1988: 25). To describe such objects solely in terms of function fails to explain the complex relationships between objects and humans. To take a concrete example, a toothbrush nominally exists to brush teeth, yet a theory of design that prioritises function - and excludes the non-functional as not proper to design - can in no way account for the vast array of toothbrush designs available to the consumer. In such cases, Baudrillard's argument is that explicit function serves as an 'alibi' for the actual purpose of the object, which is as a sign in a language-like system (Baudrillard 1981: 32).

In defining the object as 'sign', Baudrillard draws on the structuralist linguistics of Ferdinand de Saussure. Rather than explaining language in terms of historical development, Saussure contended that language is better understood when analysed as a synchronic system. Language institutes arbitrary conventions associating sounds and meanings - 'signifiers' and 'signifieds' - therefore etymology cannot reveal the nature of meaning. Further, the linguistic sign - the unity of signifier and signified — does not function in isolation, but becomes meaningful only through differential contrast with other signs (Saussure 1974: 101-103).

Baudrillard claims that objects too function as arbitrary differential signs in a communicative system. The meaning of the object lies not in its direct relationship with reality - its instrumental purpose, or its singular relationship to its owner - but in its differences with other sign-objects. Through consumption, we speak the language of sign-objects:

You never consume the object in itself (in its use-value); you are always manipulating objects [...] as signs which distinguish you either by affiliating you to your own group taken as an ideal reference or by marking you off from your group by reference to a group of higher status (Baudrillard 1988: 61).

Baudrillard was not the first to apply semiotic theory to design — semiotics was already on the syllabus at the Hochschule für Gestaltung Ulm in the 1950s (Betts 1998: 78). Nevertheless Baudrillard's appropriation of Saussurean semiology was unique as it simultaneously involved a critique of structuralism itself. Structuralism sought to develop semiology as an objective, scientific - and therefore transhistorical - method of 
analysing communication and culture. Baudrillard appropriated structuralist concepts in order to undermine structuralism's pretensions to transhistoricity. Semiology, in Baudrillard's work, becomes the name of an epoch - describing consumer society, and consumer society alone, as we have moved from a 'metallurgic into a semiurgic society' (Baudrillard 1981: 185).

Prior to the Industrial Revolution culture was not semiological but symbolic. According to Baudrillard, in symbolic society objects are not arbitrary signs but 'mediators of a real relationship or a directly experienced situation' (Baudrillard 2005: 218). In feudal periods the furniture of the ruling class did not simply signify the idea of nobility but was an actual instance of the lived experience of nobility (Baudrillard 2005: 148). The emergence of class mobility following the Industrial Revolution unhinged the object from its obligatory traditional role and liberated it perform as a signifier of an aspired-to social position (Baudrillard 1981: 49).

Consequently, the middle class may surround themselves with furniture in the style of historical aristocracy in order to signify a notional nobility - something which would have been simply impossible in feudal society. Yet, a particular object cannot definitively be categorised as an index of a particular class. The object's meaning is relational and everchanging. The rich may decorate their homes with rustic 'peasant' furniture, yet the object continues to signify class - a signification of 'peasantness' would be avoided by someone in a situation of genuine economic insecurity (Baudrillard 2005: 163). The meaning of the object continuously shifts, as fashion provides ever-new connotations.

In Design for the Real World, Papanek distinguishes 'the genuine needs of man' from 'wants inculcated by fad and fashion' (Papanek 1972: 10-11). Baudrillard dismisses the distinction between authentic and false needs as presupposing a naïve anthropology of mankind, deploying objects according to 'the "natural" anthropological needs of the individual' (Baudrillard 1981: 29). Needs - just like Papanek's 'wants' - are produced in consumer society. From access to mechanised transport, to access to the internet, that which was once the privilege of an elite - and therefore a sign of distinction - trickles down to all levels of society, becoming naturalised as need. Need and utility are the ideological justification for consumption, not the natural base upon which it is built.

\section{Function and fashion}

As Frederic J Schwartz has noted, Baudrillard's analysis was in many ways prefigured by Muthesius and other Deutsche Werkbund members (Schwartz 1996: 7-8). Specifically, the student of Design Theory will recognise Baudrillard's description of design in preindustrial societies as bound to the broader social-order, contrasted with the domination of fashion following industrialisation.

In Stilarchitektur und Baukunst, published in 1902, Muthesius distinguishes periods in which architecture was 'an essential part of the cultural endowment of the time', from the 'great stylistic confusion' of the nineteenth century (Muthesius 1994: 50, 69). In 1934's Art and Industry, Herbert Read champions Ancient Greece and Medieval Europe as producing design true to the broader culture, opposing the 'irrelevant' aesthetics of design following industrialisation (Read 1934: 1-3). Nikolaus Pevsner's Pioneers of the Modern Movement of 1936, makes a similar judgement, denouncing the 'profound artistic dishonesty' of the nineteenth century (Pevsner 1936: 20). Again, Seigfried Giedion's Mechanization Takes Command of 1948, describes the 'strong and personal bonds' between man and object, 
lost following mechanised production (Giedion 1948: 344). One could continue reciting examples of this distinction - a theoretical distinction often presented as historical fact - between the 'authentic' design of pre-industrial societies, and the 'inauthentic' design unleashed by mass production. For each of the authors cited above the inauthenticity of design at the dawn of the twentieth century demanded remedy. And for each the solution was roughly as formulated by Muthesius in 1902:

wherever possible we should for now ban completely the notion of style. When the master builder clearly refrains from any style and emphasises that which is required of him by the particular type of problem, we will be on the correct path to a contemporary art, to a truly new style (Muthesius 1994: 81).

It is here, regarding the prescription for remedy, that Baudrillard diverges. Just as he adopts structuralist analysis only to undermine the project of a transhistorical semiology, Baudrillard adopts the design theorists' account of design before and after industrialisation only to undermine the project of creating a coherent design culture for the twentieth-century.

His first argument is historical. Baudrillard claims that the very institution founded to restore coherence to design - the Bauhaus - fully unleashed the object as sign. Baudrillard argues that in rejection of nineteenth-century kitsch, the Bauhaus proposed that only the accord of form and function could realise an authentic aesthetic. The erosion of the distinction between the useful and the beautiful brought everything from the toothbrush to the towerblock - into the domain of aesthetic consideration. This 'universal semantisation of the environment' - this bringing of all into a system of signification - ironically, fully liberated the object to function as sign (Baudrillard 1981: 185). Functionalism inaugurated the condition wherein everything in the lived environment achieved semiotic value, therefore the Bauhaus was the progenitor of, and not the antidote to, the fully developed system of fashion.

Baudrillard's second argument is structural: concerning Functionalism in fully-developed consumer society. Opposing fashion, Functionalism attempts to forge a universal mode of design through successive innovations (Baudrillard 1981: 195). This, Baudrillard claims, is sheer hypocrisy. Baudrillard argues that innovation in design is identical to innovation in fashion - both exist to produce distinctive signs to be consumed (Baudrillard 1981: 47). Just as the meaning of 'peasant' furniture depends upon relational context, so too for motifs of Functionalist design. Bare concrete moves from index of poverty to signifier of sophistication, opposing the polished and lacquered aesthetic of lower classes.

In the 1960 s as designers explored expanded notions of function in reaction to the restrictiveness of the International Style, the continued justification of design in terms of function remained, according to Baurdillard, an ideological obfuscation. For example, ephemeral dwelling - advocated by Baudrillard's Utopie colleague Jungmann - was presented as a solution to modern urban living (Buckley and Violeau 2011: 72-89). To Baudrillard the ephemeral too served to distinguish class: ephemeral design was for an elite for whom the lack of a permanent, durable dwelling was not a threat.

In order to avoid taking this ideological process into account, designers exhaust themselves in popularising audacious 'rational', 'functional' forms, being all the while surprised that these forms do not spontaneously seduce the mass public [...] these 'popular' creators direct their unconscious strategy: beautiful, stylised, 
modern objects are subtly created in order not to be understood by the majority - at least not straight away. Their social function first is to be distinctive signs, to distinguish those who distinguish them (Baudrillard 1981: 48).

\section{Conclusion}

Decades before post-structuralist references became common currency among designers, Baudrillard - a key post-structuralist - critically engaged with the central themes of twentieth-century Design Theory, arriving at the conclusion that Functionalism - the very thing supposed to oppose fashion — was in fact fundamental to fashion's development. Baudrillard's arguments may not be at all times plausible, and may be of limited use to the practising designer. In defining 'consumption' over 'use' as the fundamental determinant of design, Baudrillard refutes the egalitarian agenda of Functionalism as ideological naïvety. Unlike Archizoom Associati who in the 1960 s also recognised consumption usurping use (Branzi 1984: 54-55), Baudrillard offers no prospect for the harnessing of this fact by progressive design.

Nevertheless, his argument is in a sense more solidly grounded than Functionalism. Functionalism was justified according to an always as-yet-unfulfilled Utopia: a time after fashion. Baudrillard's critique arose from an analysis of the consumer society of his time, and it was in that present - not a hypothetical future - that he found Functionalism wanting.

As design discourse today increasingly becomes a consumer object, and the design conference a commercial enterprise, the lecture-touring designer is obliged to inspire and entertain a market of design students and enthusiasts. Baudrillard's disengagement with the concerns of the practising designer, points to a today relevant mode of Design Theory: a necessarily distanced, and unromanticised, perspective from which to theorise design.

\section{References}

Betts, P. (1988) 'Science, Semiotics and Society: The Ulm Hochschule für Gestaltung in Retrospect', Design Issues, vol. 14, no. 2, Summer, pp. 67-82.

Baudrillard J. (1981) For a Critique of the Political Economy of the Sign, translated by Levin, C., St. Louis, MO: Telos Press.

Baudrillard J. (1988) The Consumer Society, translated by Turner, C., London: Sage. Baudrillard J. (2005) The System of Objects, translated by Benedict, J., London: Verso. Branzi, A. (1984) The Hot House: Italian New Wave Design, translated by Evans, C.H., London: Thames and Hudson.

Giedion, S. (1948) Mechanization Takes Command, New York, NY: Oxford University Press. Gropius, W. (1935) The New Architecture and The Bauhaus, translated by Shand, P. M., London: Faber and Faber.

Jencks, C. (1973) Modern Movements in Architecture, New York, NY: Anchor Press. Buckley, C. and Violeau, J-L. (ed.) (2011) Utopie: Texts and Projects, 1967-1978, London: Semiotext(e).

Muthesius, H. (1994) Style-Architecture and Building-Art, translated by Anderson, S., Santa Monica, CA: The Getty Centre.

Papanek, V. (1972) Design for the Real World, London: Thames \& Hudson.

Pevsner, N. (1936) Pioneers of the Modern Movement, London: Faber and Faber.

Read, H. (1934) Art and Industry, London: Faber and Faber.

Saussure, F. de (1974) Course in General Linguistics, translated by Baskin, W., Glasgow: Collins. Schwartz, F.J. (1996) The Werkbund: Design Theory and Mass Culture before the First World War, London: Yale University Press.

Venturi, R. (1966) Complexity and Contradiction in Architecture, New York, NY: The Museum of Modern Art. 